\title{
Water Basin Delimitation in a Relief Transition Region
}

\author{
Kevin Ficher $^{1}$ (D), Donizete Pereira ${ }^{1}$ (D), André Almeida ${ }^{2}$ (D), Josiane Oliveira ${ }^{1}$ (D) \\ ${ }^{1}$ Universidade Federal de Viçosa - UFV, Florestal/MG, Brasil \\ ${ }^{2}$ Universidade Federal de Sergipe - UFS, São Cristóvão/SE, Brasil
}

\begin{abstract}
The objective of this work was to evaluate the performance accuracy of digital elevation models in delimiting a water basin located in the relief transition region between the São Francisco Plateau, São Franciscana Depression and the Espinhaço mountain range. Four digital elevation models with data from the Shuttle Radar Topographic Mission (SRTM) and map topography were generated using the Topo To Raster interpolator with and without support from hydrography maps (IBGE), and another with the original SRTM data. For each digital elevation model, its accuracy was evaluated for representing: the drainage, the hydrography and basin mouth in comparison to the references obtained from IBGE maps. The models generated with SRTM and topographic data supported by hydrography maps showed good performance, with small delimitation errors in the water basin. Those generated without support from hydrography maps showed gross errors due to non-representation of the hydrography in the São Franciscana Depression region.
\end{abstract}

Keywords: SRTM, topographic maps, interpolation. 


\section{INTRODUCTION}

A water basin is understood as a natural catchment area of precipitation, topographically delimited by a water divider which converges flows to a single outlet called the mouth (Ferrari et al., 2013). A water basin is of fundamental importance for water resources, as they are the planning and management units adopted by the National Water Resources Policy, instituted by Law No. 9,433 from January 8, 1997.

A basin must be identified and delimited following the dynamics and conformation of the drainage network to which it is connected (Bertoni \& Lombardi, 2008; Ferrari et al., 2013). Correct delimitation of its water dividers and its drainage network is of great importance for studies related to modeling flows, erosive processes, transport and deposition of chemical pollutants, as well as in predicting floods and understanding geomorphological, geological and pedological issues (Ceballos \& Schnabel, 1998; Ribeiro et al., 2005), and should be the first step in the representation of the study area (Seyler et al., 2009).

Delimiting water basins has been performed automatically using the tools available in most Geographic Information Systems (GIS) (Garbrecht \& Martz, 1993; Ribeiro et al., 2005). Algorithms are used in this process which identify the water dividers and hydrography from a matrix representation of the terrain's topography, called the Digital Elevation Model (DEM) (Fairfield \& Leymarie, 1991; Choi \& Engel, 2003; Alves et al., 2010; Cecílio et al., 2013).

Using DEM to obtain the drainage network and to delineate basins was stimulated from developing the algorithm Deterministic-8Node (D8) (O'Callaghan \& Mark, 1984; Seyler et al., 2009). This algorithm determines that in a grid of cells which represent the altimetric relief values, water flow happens from each cell to one of its eight neighbors (orthogonal and diagonal) in the direction of the highest slope (Ribeiro et al., 2005).

DEMs are currently obtained through remote sensor images (radars) or from interpolating topographic data points and contour lines extracted from topographic maps or planialtimetric surveys (Pinheiro, 2006; Oliveira et al., 2010; Cecílio et al., 2013). Depending on the DEM characteristics such as scale, resolution and origin, automatic delimitation of a basin may differ significantly (Ribeiro et al., 2005; Alcaraz et al., 2009; Seyler et al., 2009; Medeiros et al., 2009; Cecílio et al., 2013; Rawat et al., 2014).

Ribeiro et al. (2005) compared the quality and accuracy of DEMs generated by IDW, SPLINE and TOPOGRID interpolators and obtained better results with TOPOGRID and SPLINE. Cecílio et al. (2013) evaluated the automatic delimitation of a river basin located in a mountainous region from six different DEMs: three DEMs originating from radar imaging (SRTM) and their refinements; and three DEMs originating from spatial interpolation processes of contour lines. The authors verified that the DEM generated from the contour lines and hydrography mapped using the Topo To Raster interpolator better represented the basin relief for delimitation purposes. Rawat et al. (2014) evaluated the effects of DEM resolution on delimiting the water dividers of a sub-basin in Shahjahanpur, India. The authors evaluated a DEM with a resolution of $2.6 \mathrm{~m}$ (DEM CARTOSAT-1), one with a resolution of $30 \mathrm{~m}$ (ASTER DEM) and another with a resolution of $90 \mathrm{~m}$ (SRTM DEM). They obtained a better accuracy in delimiting the basin with the resolution of $2.6 \mathrm{~m}$, and much better precision with that of $90 \mathrm{~m}$ in comparison to the one with greater spatial resolution $(30 \mathrm{~m})$.

Considering the above, we have not found any studies evaluating DEM performance obtained by different techniques in relief transition regions. Thus the objective of this work was to evaluate the accuracy of digital elevation models generated from SRTM data and topographic charts using different techniques in delimiting a river basin located in a transition region between the São Francisco Plateau, São Franciscana Depression and Espinhaço mountain range in Minas Gerais state, Brazil.

\section{MATERIAL AND METHODS}

\subsection{Study area}

The study was conducted for the Peixe River water basin, which has a drainage area of approximately $580 \mathrm{~km}^{2}$ located in one of the most important hydrographic basins of the country, the São Francisco River. It is located in the central region of Minas Gerais state, between the coordinates of $19^{\circ} 25^{\prime} 00^{\prime \prime}$ and $19^{\circ} 42^{\prime} 00^{\prime \prime} \mathrm{S}$ and $44^{\circ} 40^{\prime} 00^{\prime \prime}$ and $45^{\circ} 00^{\prime} 00^{\prime \prime} \mathrm{W}$, in a transition region between the São Francisco Plateau, the São Franciscana Depression and 
the Espinhaço mountain range (Figure 1). The basin covers the municipalities of Pitangui, Onça do Pitangui, Pompeu, Maravilhas and Papagaio.

The São Francisco Plateau consists of tabular surfaces called chapadas, with predominantly sandy sedimentary cover bordered by erosive ridges well-marked in the landscape and intersected by deep drainage headwaters known as waterpaths. The tabular reliefs are distinguished in two levels of altitude: one ranging from 800 to $1000 \mathrm{~m}$, and the other from 600 to $800 \mathrm{~m}$ (IGA, 2016).

The São Franciscana Depression develops along the São Francisco River drainage, where flattened relief forms, wavy surfaces and ragged pediments predominate. The extensive recessed areas show prevailing altitudes around $500 \mathrm{~m}$. The landscape shows more rugged relief close to the Espinhaço mountain range, where hills and crests with ravined slopes and embedded valleys predominate (IGA, 2016).

The Espinhaço mountain range is a large water divider interposed between the central-east Brazil basins and that of the São Francisco River. In Minas Gerais, it constitutes a set of uplands with a boomerang form in the general north-south direction with convexity orientated to the west (Saadi, 1995) with predominance of crests, peaks, and embedded valleys, as well as slightly wavy relief forms to a lesser extent (Sodré et al., 2007).

The region's climate is Cwa (mesothermic tropical altitude) according to the Köppen classification, presenting dry winters and mild summers with an average lower than $19{ }^{\circ} \mathrm{C}$ in the coldest month. The predominant vegetation is medium-sized cerrado, with patches of perennial forests and semi-deciduous occurring (Romano \& Soares, 2007). The soils present in the basin are: Red Latosol; Red-yellow Latosol; Red Argisol and Red-yellow Argisol (IBGE, 2002).

\subsection{Delimitation of water dividers, representation of the hydrography and mouth}

Delimiting the water dividers, as well as the representativeness of the water basin's hydrography and mouth, was performed via five different digital

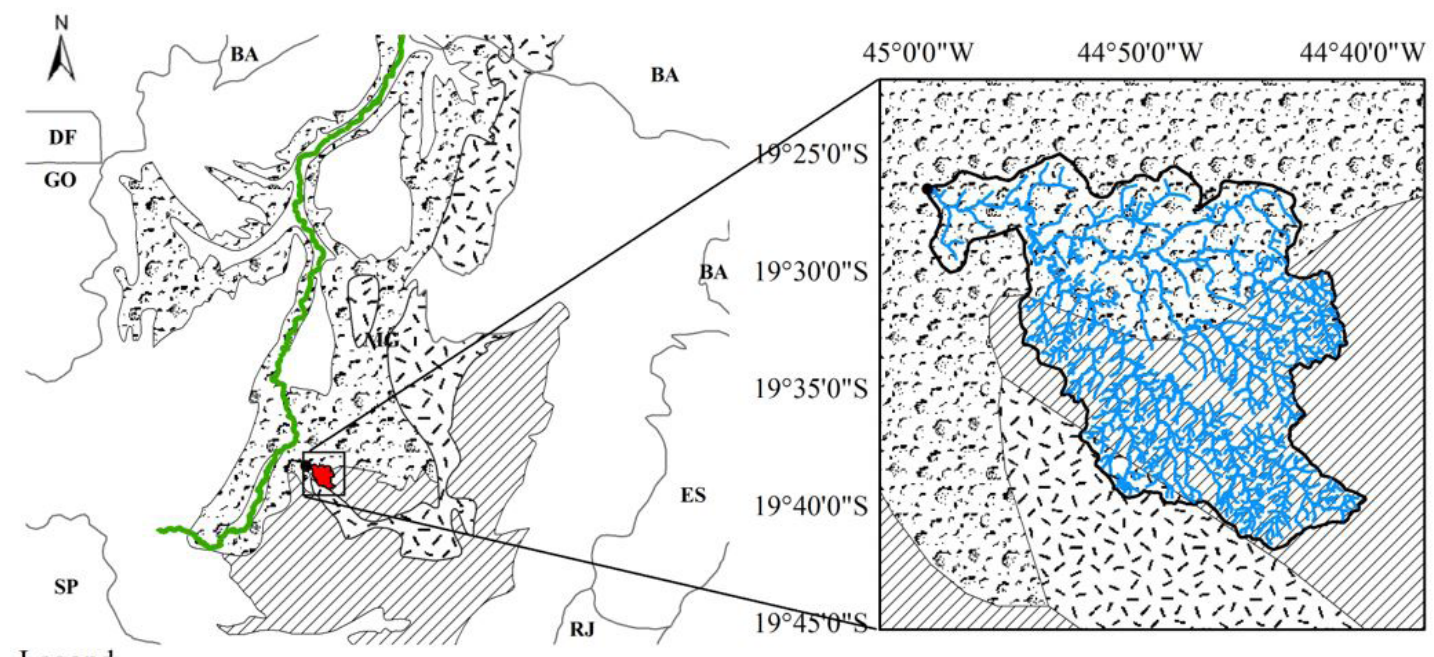

Legend

- Mouth

- Hydrography

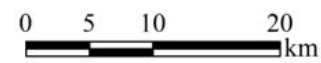

— São Francisco River

$\square$ Brazil

Peixe River Basin

… São Franciscana Depression

U/A São Francisco Plateau

[1. Espinhaço Mountain Range

Figure 1. Location of the study area. 
elevation models obtained from different techniques (Table 1). Three of these models were elaborated based on the matrix representation obtained by radar interferometry called Shuttle Radar Topography Mission (SRTM) (Rabus et al., 2003). The other two were obtained from interpolating the contour lines obtained from planialtimetric maps from the Brazilian Institute of Geography and Statistics (IBGE), in the scale of 1:100,000. The IBGE planialtimetric maps have information on hydrography (mapped) and altimetry (50 $\mathrm{m}$ equidistance contour lines) referring to the Pará de Minas (042533) and Pompeu (042495) sheets, available in vector format. It should be noted that this scale was used because these data are not available on a larger scale.

SRTM data were obtained from the Brazilian Agricultural Research Corporation (EMBRAPA), with a spatial resolution of $90 \times 90 \mathrm{~m}$ and WGS84 datum. One DEM was elaborated from the original SRTM matrix representation. The other two were obtained by adapting the methodology of Valeriano \& Abdon (2007), described as: first, contour lines with equidistance of $20 \mathrm{~m}$ were generated from the SRTM for the entire length of the basin; next, the contour lines were interpolated through the Topo To Raster interpolator with and without the IBGE hydrography support (mapped), respectively generating the DEMs denominated SRTM-TRH and SRTM-TR, both with spatial resolution of $10 \times 10 \mathrm{~m}$ (Table 1). It should be noted that the DEMs were previously georeferenced using the ArcGis 9.3 georeferencing extension, adjusting the raster image (DEM) to the georeferenced mesh (vector file.dgn) using the Auto Adjust and $1^{\text {st }}$ order polynomial error, observing an acceptable limit of 10 for the total RMS Error.

The other DEMs were obtained by interpolating the IBGE map contour lines using the Topo To Raster interpolator with and without mapped hydrography support, respectively generating the DEMs denominated TM-TRH and TM-TR, both with spatial resolution of $10 \times 10 \mathrm{~m}$ (Table 1). It should be noted that choosing the Topo To Raster interpolator was based on the results obtained in other studies that proved its effectiveness in interpolating data.

ArcGIS 9.3 software (ESRI, 2008) was used in order to obtain the DEMs from different techniques, as well as for the automatic delimitation of the water dividers, for the hydrographic representation and the mouth of the water basin, which were determined using the Spatial Analyst and Hydrology Modeling extensions and based on the Deterministic-8Node algorithm (O'Callaghan \& Mark, 1984). Firstly, spurious depressions (cells surrounded by others with higher elevation values) were identified and eliminated (which can cause distortions in the drainage network and make it impossible to trace the water dividers) (Oliveira et al., 2010) using the Fill Sinks command. Next, the flow directions were defined using the Flow Direction command, the accumulated flow (Flow Accumulation command) and the automatic delimitation of the basin (Watershed command). The hydrography was generated from the accumulated flow, adopting a value of 500 in the Raster Calculator tool as the minimum number of cells for flow generation denominated numerically.

\subsection{Evaluation of Digital Elevation Models (DEMs)}

In order to evaluate the accuracy of the DEMs obtained by different techniques, delimitations of the water dividers, the hydrographic representation and the Peixe River water basin mouth were determined from each DEM and compared with their references: the delimitation of the water dividers performed

Table 1. Digital elevation models assessed in delimiting water dividers, hydrography and the mouth of the Peixe River water basin.

\begin{tabular}{clcc}
\hline Code & Database & $\begin{array}{c}\text { Interpolator/ } \\
\text { representation utilized }\end{array}$ & Spatial resolution \\
\hline SRTM-O & SRTM Image & - & $90 \times 90 \mathrm{~m}$ \\
SRTM-TR & SRTM Image & TR & $10 \times 10 \mathrm{~m}$ \\
\hline SRTM-TRH & SRTM Image & TRH & $10 \times 10 \mathrm{~m}$ \\
TM-TR & Topography maps & TR & $10 \times 10 \mathrm{~m}$ \\
\hline TM-TRH & Topography maps & TRH & $10 \times 10 \mathrm{~m}$ \\
\hline
\end{tabular}

SRTM = Shuttle Radar Topography Mission; TM = Topography Maps; $\mathrm{O}=$ original; TR = Topo To Raster without mapped hydrography support; TRH $=$ Topo To Raster with mapped hydrography support. 
manually from topographic charts, and the hydrography and mapped data obtained from IBGE. ArcGIS 9.3 software and topographic maps mentioned above were used to this purpose.

The accuracy of the DEM was evaluated by submitting each DEM to the following criteria (Ribeiro et al., 2005; Pinheiro, 2006; Lindsay et al., 2008; Cecílio et al., 2013; Rawat et al., 2014): a) minimum and maximum altitude and relative error in determining the drainage area; b) error in the water basin's mouth location obtained from the location difference in a straight line; c) visual comparison between mapped and numerical hydrography (obtained with the DEM); and d) visual comparison between the reference water dividers and the dividers obtained from the DEM. It should be noted that the relative error was obtained by the difference (in the module) between the reference value and that obtained with the DEM, divided by the reference value.

\section{RESULTS AND DISCUSSION}

Table 2 shows the drainage areas and the minimum and maximum altitudes obtained automatically by means of the different evaluated DEMs, and manually by reference.

In general, we obtained the best results with the models generated using mapped hydrography support (SRTM-TRH and TM-TRH) (Table 2). Considering only the drainage area of the basin, the model that presented the best estimates was generated from the SRTM data using the Topo To Raster interpolator with the mapped hydrography support (SRTM-TRH). It has an estimation error of $0.4 \%$ compared to that obtained from the reference delimitation $\left(578.8 \mathrm{~km}^{2}\right)$, which shows the accuracy of this technique for obtaining the DEM. Cecílio et al. (2013) obtained an error of only $0.04 \%$ in evaluating different DEMs in delimitating the Prata River Basin, Espírito Santo state, obtaining the drainage area using the TM-TRH DEM, which was considered by the authors as having the best performance for delimiting the basin. In the present study, although it was not the best DEM for delimiting the basin, good estimates were also obtained with the TM-TRH DEM with a relative error of only $1.1 \%$, also proving the accuracy of the technique for obtaining this DEM. It should be noted that these differences found between the studies are associated to the different topographic characteristics between the basins, especially with respect to the flat areas, which are lower in the case of the basin used by Cecílio et al. (2013) than in this study.

In using the DEMs generated without the hydrography support (SRTM-O, SRTM-TR and TM-TR), it can be observed that good estimates were not obtained in delimiting the Peixe River Basin, with differences in drainage area of 104.8, 104.8 and $154.8 \mathrm{~km}^{2}$ for SRTM-O, SRTM-TR and TM-TR respectively, compared to the reference delimitation, which is equivalent to relative errors of 18.1, 18.1 and 26.6\% (Table 2). These values are considered high when compared to those obtained in the literature, mainly those found by Cecílio et al. (2013), who obtained errors up to $1.8 \%$ in the drainage area using these DEMs in delimiting the Prata River basin. It should be noted that the authors tested the models in a mountainous region with different topographic conditions than the region of the present study, which is a transition of extensive flat area with more pronounced relief areas. Error close to the present study and also in flat relief regions was obtained by Seyler et al. (2009) when evaluating SRTM DEM in delimiting sub-basins in Amazonas State in the northern region of Brazil. The authors obtained an error of $17.4 \%$ in delimiting the drainage area for one of the studied basins.

Table 2. Drainage area $(\mathrm{Ad})$ and minimum $\left(\mathrm{A}_{\min }\right)$ and maximum $\left(\mathrm{A}_{\max }\right)$ altitudes of the Peixe River Water Basin obtained automatically by the DEM and manually (reference).

\begin{tabular}{ccccc} 
Code & $\mathbf{A d}\left(\mathbf{k m}^{2}\right)$ & Relative error $(\%)$ & $\mathbf{A}_{\max }(\mathbf{m})$ & $\mathbf{A}_{\min }(\mathbf{m})$ \\
\hline Reference & 578.8 & - & 1200 & 600 \\
\hline SRTM-O & 683.6 & 18.1 & 1214 & 611 \\
\hline SRTM-TR & 683.6 & 18.1 & 1218 & 610 \\
\hline SRTM-TRH & 581.0 & 0.4 & 1215 & 601 \\
\hline TM-TR & 733.0 & 26.6 & 1225 & 579 \\
\hline TM-TRH & 572.3 & 1.1 & 1223 & 593 \\
\hline
\end{tabular}

SRTM = Shuttle Radar Topography Mission; TM = Topographic maps; $\mathrm{O}=$ original; TR = Topo To Raster without mapped hydrography support; TRH $=$ Topo To Raster with mapped hydrography support. 
Regarding the maximum and minimum altitude values, the best estimate was also observed when using SRTM-TRH DEM. We obtained a difference of 1 and $15 \mathrm{~m}$ in the minimum and maximum altitude for this model, respectively, in comparison to the reference. The worst estimate was observed using the TM-TR model, with a difference of 21 and $25 \mathrm{~m}$ in the minimum and maximum altitude, respectively. Adequate estimation of the minimum altitude is of fundamental importance for delimiting the basin since it is directly related to its mouth, and errors in its estimation can cause great errors in delimiting basins, which was verified in the present study in using DEM generated without mapped hydrography support (Figures $2 \mathrm{~b}, 2 \mathrm{c}$ and $2 \mathrm{e}$ ).

Figure 2a shows the Peixe River Basin inserted between the Espinhaço mountain range, São Francisco Plateau and São Franciscana Depression. Figures $2 b$ to $2 f$ show the location of the Peixe River basin mouth, delimited from the evaluated DEMs and the manual procedure (reference). It is emphasized that the reliefs were not inserted in Figures $2 \mathrm{~b}$ to $2 \mathrm{f}$ for clarity.

As with determining the drainage area and the altitudes (minimum and maximum), the errors verified in determining the basin's mouth were smaller when using the DEM generated with the mapped hydrography support (Figures $2 \mathrm{~d}$ and $2 \mathrm{f}$ ), which are visually imperceptible. A large difference between the actual mouth and those obtained using the DEM without the mapped hydrography support (Figures $2 \mathrm{~b}, 2 \mathrm{c}$ and $2 \mathrm{e}$ ) is also visually observed. Considering a straight line, the difference in location between the actual mouth and those generated automatically were: $9,303.3 \mathrm{~m}$ for SRTM-O; 9,179.1 m for SRTM-TR; 10,606.2 m for TM-TR; $165.0 \mathrm{~m}$ for TM-TRH; and $13.1 \mathrm{~m}$ for SRTM-TRH. The differences in the actual mouth location and those obtained with the DEMs without the hydrography support are large, mainly when compared to those found by Cecílio et al. (2013) for the Prata River basin, Espírito Santo state. These authors found a location difference of 614,421 and $71 \mathrm{~m}$ between the actual basin mouth and those generated using SRTM-O, SRTM-TR and TM-TR, respectively.

According to Cecílio et al. (2013), the errors made in determining the mouth are associated with hydrography mischaracterization by using a simulation of rectilinear water courses in flatter areas. This observation made by the authors was verified in the present study, as can be observed in Figures $2 b, 2 c$, and 2e. Note that

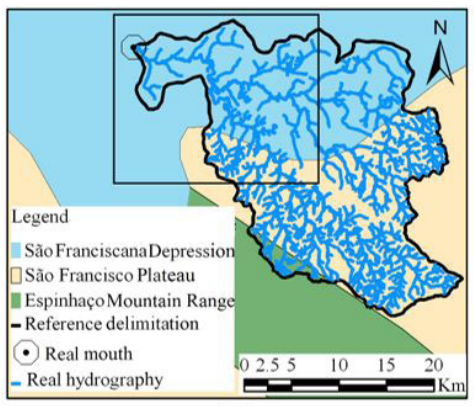

(a)

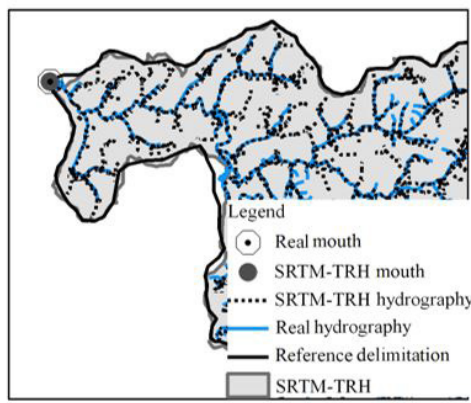

(d)

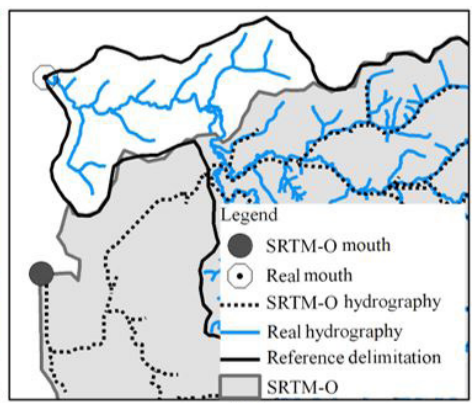

(b)

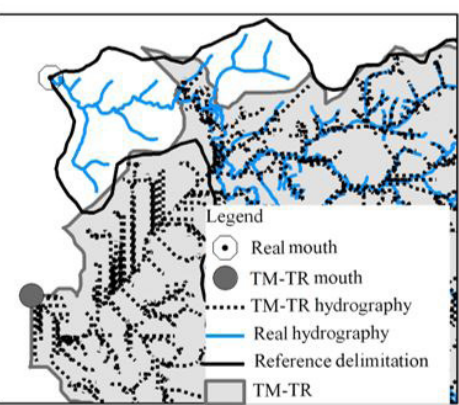

(e)

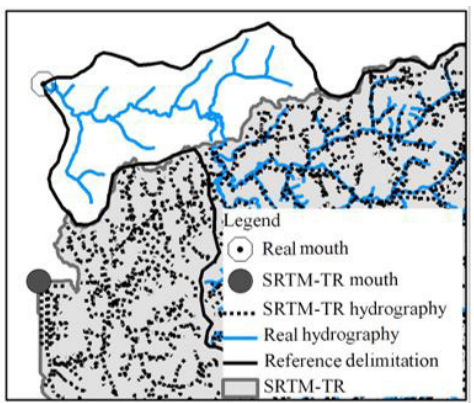

(c)

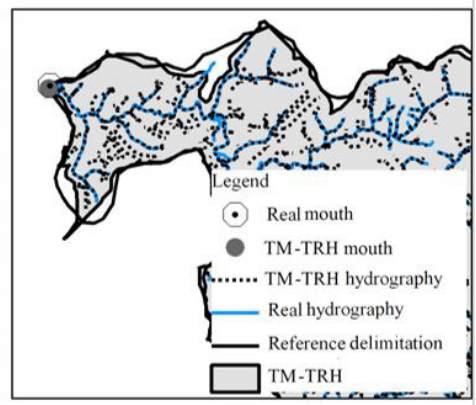

(f)

Figure 2. Location of the real Peixe River Water Basin mouth and those obtained using the various evaluated Digital elevation models (DEMs). 
the hydrography generated with SRTM-O (2b), SRTM-TR (2c) and TM-TR (2e) cuts the real water divider of the basin. It diverts the Peixe River (main river from the basin) to a neighboring basin due to the mischaracterization of the numerical hydrograph (generated with the DEMs) in the São Franciscana Depression region, as can be verified when comparing the respective figure with Figure 2a. However (Figures 3a to 3f), by using the DEMs generated with mapped hydrography support (Figures $3 \mathrm{~d}$ and $3 \mathrm{f}$ ), we can see a good fit of the numerical hydrograph to the mapped one by the overlapping hydrographs. These results demonstrate the accuracy and the necessity of using mapped hydrography as a support to generate the DEM in order to force the Topo To Raster algorithm to generate the numerical hydrograph with greater precision in the São Franciscana Depression region, as its flattened relief form hinders better characterization.
Other studies also suggest that hydrography be used as a support to strengthen the drainage network location of a basin (Fairfield \& Leymarie, 1991; Ribeiro et al., 2005; Cecílio et al., 2013).

Figure 3 a shows the clearest errors made using the SRTM-O DEM in delimiting the Peixe River Basin water dividers, which is inserted in the transition region between the São Francisco Plateau, São Franciscana Depression and Espinhaço mountain range. These errors are presented in greater detail in Figures $3 b, 3 c$ and $3 d$, emphasizing that the relief information was not inserted for clarity.

Three of the clearest errors in basin delineation using the SRTM-O DEM compared to the reference (actual water divider) are shown in Figure 3a. A large part of the drainage area and the hydrography of the neighboring basin (number 1 - Figure $3 \mathrm{~b}$ ) are also included, as well as the exclusion of a large part of

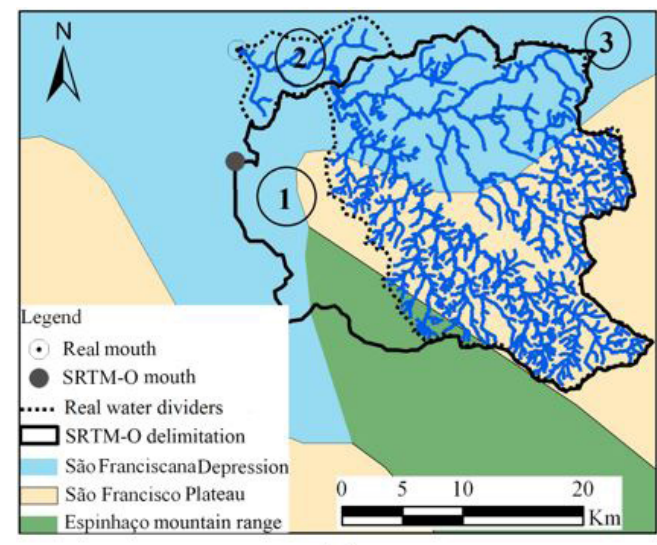

(a)

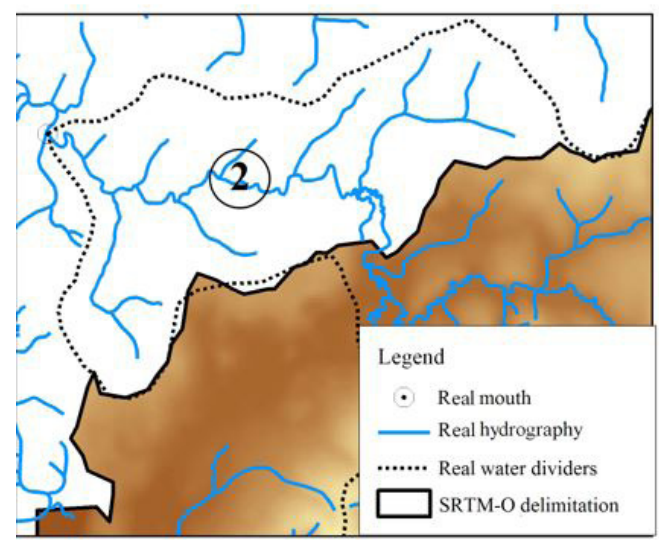

(c)

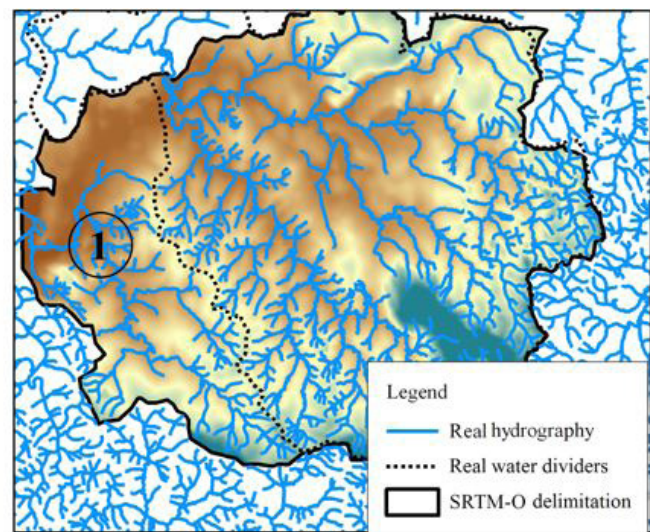

(b)

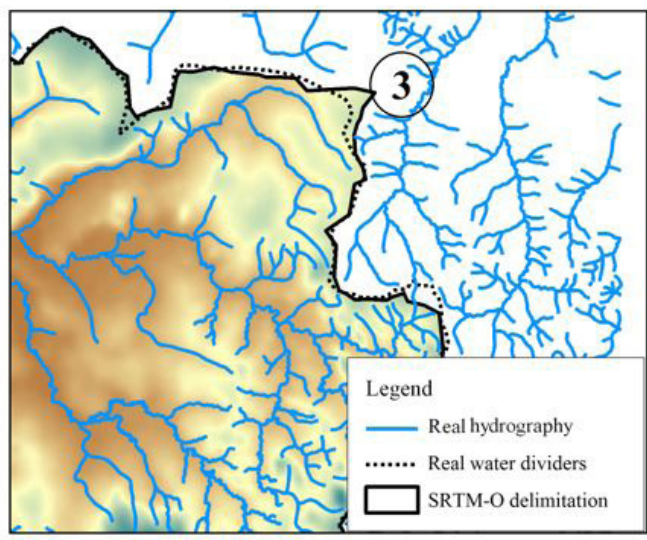

(d)

Figure 3. Main errors made in delimiting the Peixe River Basin water dividers using the Shuttle Radar Topography Mission original (SRTM-O DEM). 
the basin drainage area towards the mouth (number 2 - Figure 3c). These errors were caused due to a gross error in which the main river of the basin (Peixe River) was cut by the water dividers delimited with this DEM in the São Franciscana Depression region, as can be visualized by comparing Figures $3 \mathrm{a}$ and $3 \mathrm{c}$. Small inclusion and exclusion errors of drainage areas (number 3) can also be observed (Figure 3d) in areas of the São Franciscana Depression and in the São Francisco Plateau (Figure 3a). Based on these errors ( 1 and 2 ) and on the large errors made in determining the drainage area and the location of the Peixe River basin mouth, it can be inferred that SRTM-O presented poor performance and should not be used for studies in the region.

The errors found between the reference delimitation and that obtained with the elevation model generated from the SRTM without the hydrographic mapped support (SRTM-TR) can be seen in Figures $4 \mathrm{a}$ to $4 \mathrm{~d}$.

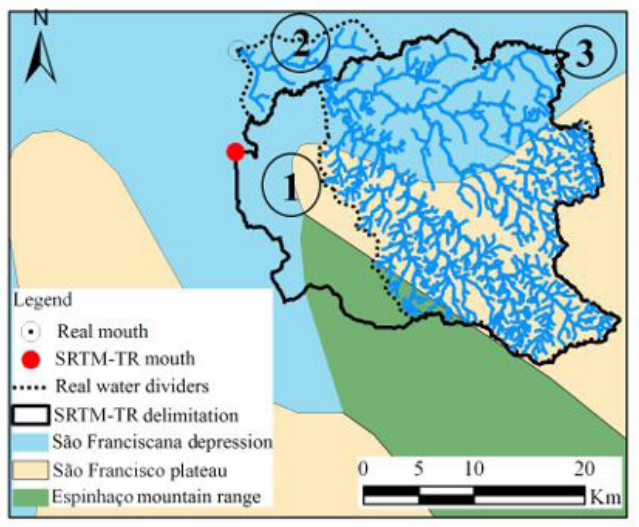

(a)

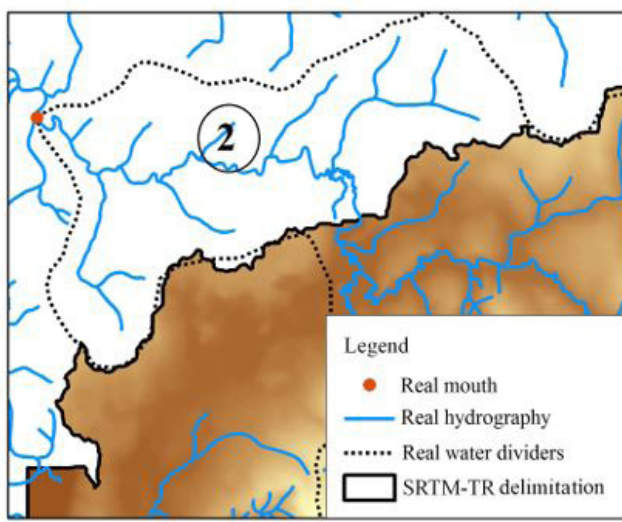

(c)
Thus, as in SRTM-O, a large inclusion of drainage area and hydrography of the neighboring basin was observed (Figure $4 \mathrm{~b}$ ), as represented by number 1 ; the exclusion of a good part of the drainage area and hydrography of the basin in the mouth direction (number 2 - Figure 4c); and small inclusions and exclusions of drainage area (number 3 - Figure 4d). Errors 1 and 2 were also caused by the gross error in which the main river of the basin was cut by the water dividers delimited with this DEM in the São Franciscana Depression region (Figures $4 \mathrm{a}$ and $4 \mathrm{c}$ ). Thus, it is seen that the errors made with the SRTM-TR were practically the same as with the SRTM-O. The pixel size reduction from $90 \times 90 \mathrm{~m}($ SRTM-O) to $10 \times 10 \mathrm{~m}($ SRTM-TR) interpolated by using Topo To Raster did not show improvements. Therefore the DEM obtained by this technique (just as SRTM-O) should not be used for on-site studies.

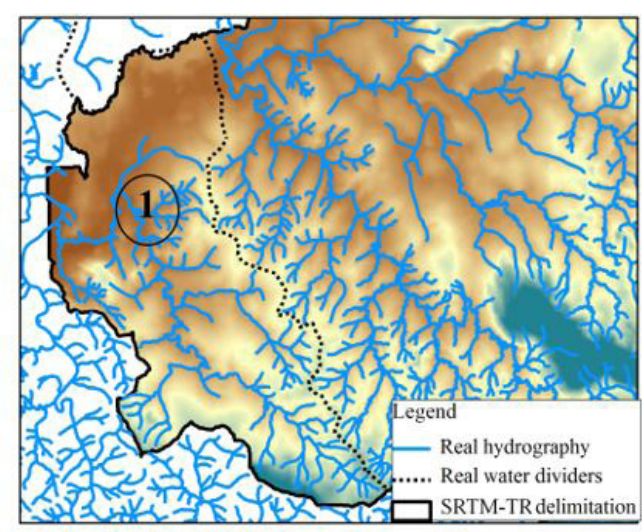

(b)

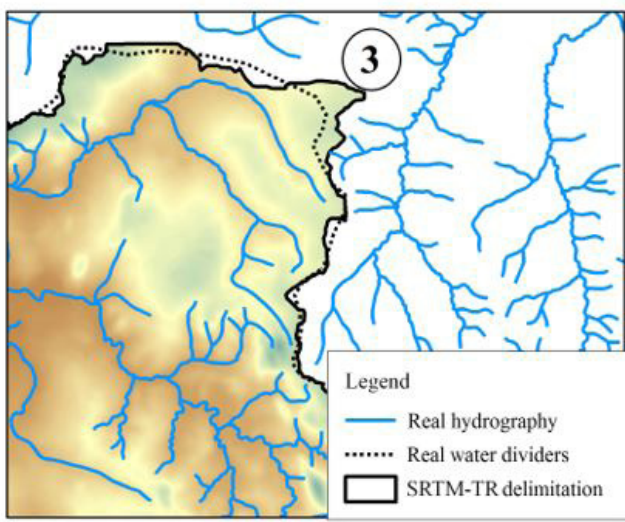

(d)

Figure 4. Main errors made in delimiting the Peixe River Basin water dividers using the SRTM without the hydrographic mapped support (SRTM-TR DEM). 
Figures $5 \mathrm{a}$ to $5 \mathrm{c}$ show the main errors in delimiting the water dividers using the SRTM-TRH DEM in comparison to the reference (actual water divider).

One of the best results was obtained from the studied models, evidencing the technique's effectiveness in associating the basin's hydrography (mapped) when performing DEM interpolation. Inclusion and exclusion errors of drainage areas were few (Figures $5 b$ and $5 c$ ), which are only limited to the São Franciscana Depression region. Therefore this corroborates the best drainage area estimate and minimum altitude of the basin (Table 2), thereby qualifying the SRTM-TRH DEM as having great precision for studies on the Peixe River water basin. The models generated with the mapped hydrography support also presented the best results in other automatic delimitation studies of water basins like those of Alcaraz et al. (2009), Medeiros et al. (2009) and Cecílio et al. (2013).

The clearest errors in delimiting the Peixe River basin are presented in Figures $6 a$ to $6 f$ by use of the TM-TR DEM in comparison to the reference (real water divider).

In addition to the greater errors in the mouth location, in estimating the drainage area and worse performance in estimating the minimum altitude of the basin (Table 2) compared to the other studied DEMs,

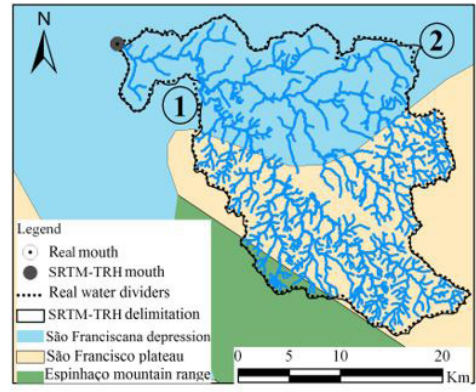

(a)

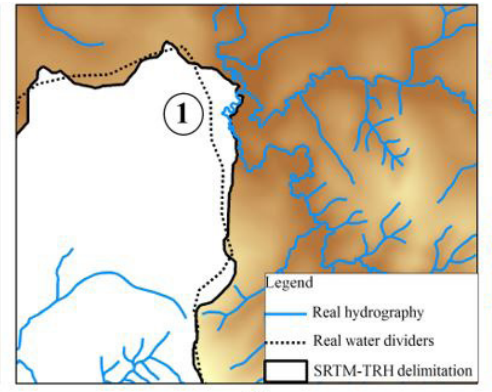

(b)

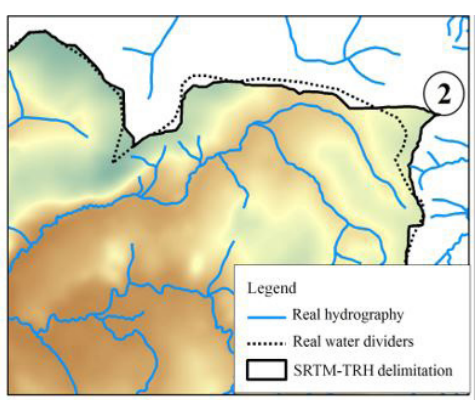

(c)

Figure 5. Main errors made in delimiting Peixe River Basin water dividers using the SRTM with the hydrographic mapped support (SRTM-TRH DEM).

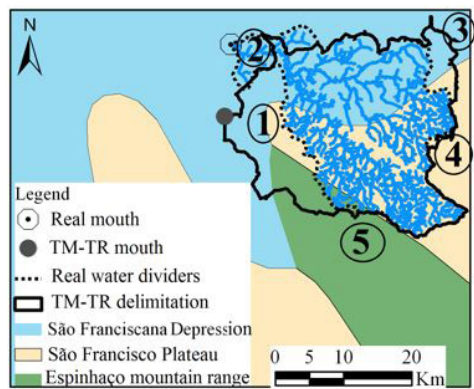

(a)

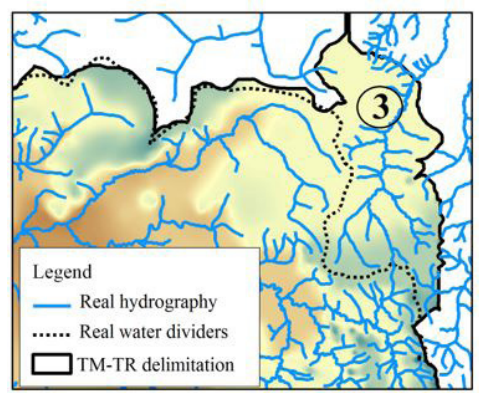

(d)

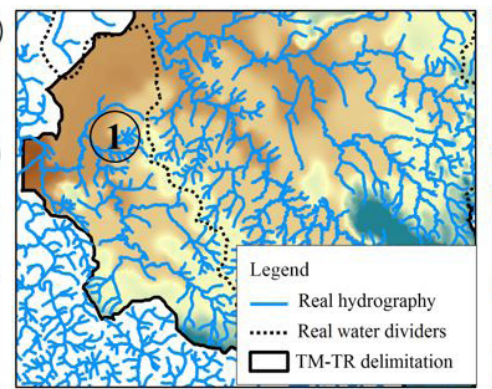

(b)

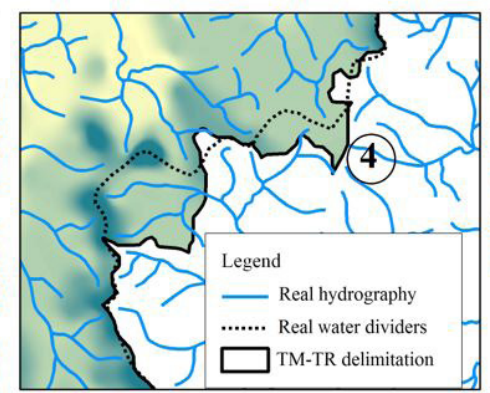

(e)

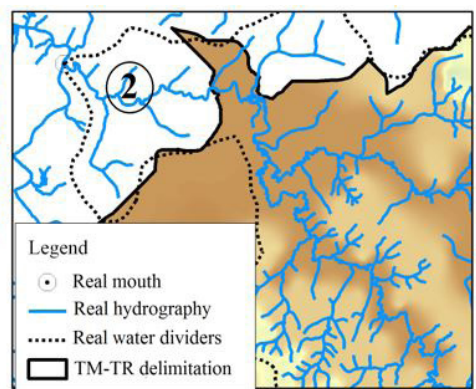

(c)

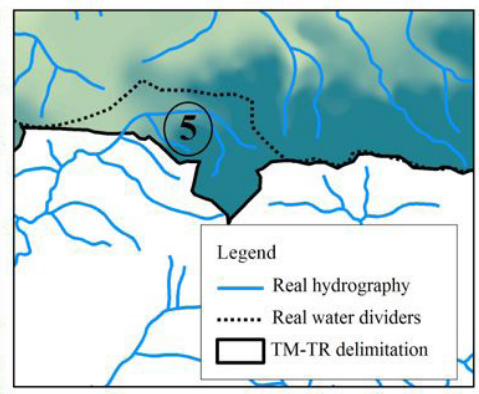

(f)

Figure 6. Main errors made in delimiting the Peixe River Basin water dividers using the IBGE topographic maps without mapped hydrography support (TM-TR DEM). 
more errors were made with this model in delimiting the basin's water dividers (Figure 3a). The errors (1 and 2) observed with the other models generated without the mapped hydrography support were also observed (Figures $3 \mathrm{~b}$ and $3 \mathrm{c}$ ), because the main river of the basin (Peixe River) was cut by the water dividers delimited with this DEM. However, this occurred in a slightly higher region of the São Franciscana Depression than the SRTM-O and SRTM-TR DEMs. These errors caused by using these three DEMs serve as an alert to the academic community and water managers about the need to verify the accuracy of the DEM prior to its use, since such serious errors can compromise all the environmental planning of the basin.

Other errors which were not committed by the other models were observed using TM-TR, such as the inclusion of a good part of the area and the hydrography of another neighboring basin (number 3) in areas of the São Francisco Plateau and São Franciscana Depression (Figures $6 \mathrm{a}$ and $6 \mathrm{~d}$ ). There were also minor

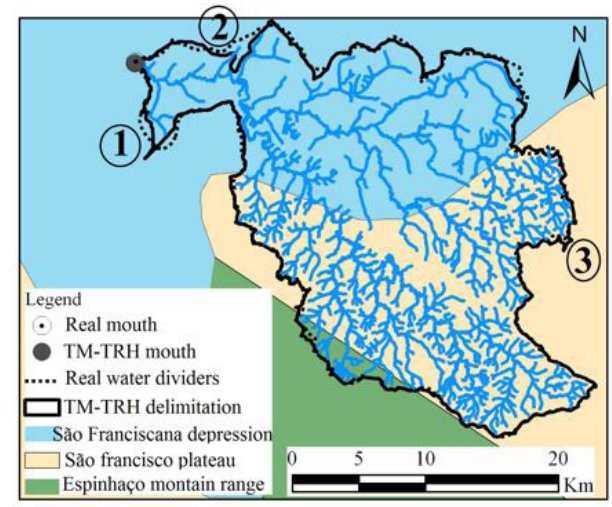

(a)

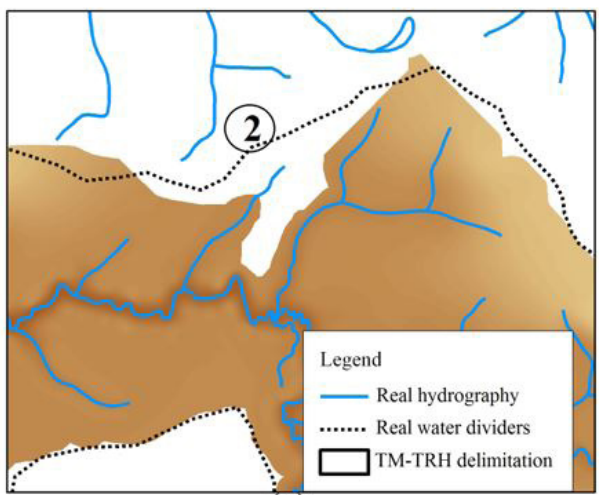

(c) errors of including drainage area and hydrography of neighboring basins in areas of the São Francisco Plateau and Espinhaço mountain range (Figures 6a, 6e and 6f).

In other studies such as those by Ribeiro et al. (2005) and Cecílio et al. (2013), satisfactory results have been observed with the use of this DEM by using topographic maps at a scale of 1:50,000. The scale of the planialtimetric maps used $(1: 100,000)$ possibly influenced the delimitation errors of the basin by using this DEM a little. However it is evident that the reason for large errors is not associated with this, but to the distinct relief characteristics in which the basin is located.

Figures $7 \mathrm{a}$ to $7 \mathrm{~d}$ show the main errors made using the DEM generated from IBGE topographic maps with mapped hydrography support (TM-TRH).

Differently from the TM-TR DEM without hydrography support, the TM-TRH DEM presented good results in estimating the Peixe River basin water

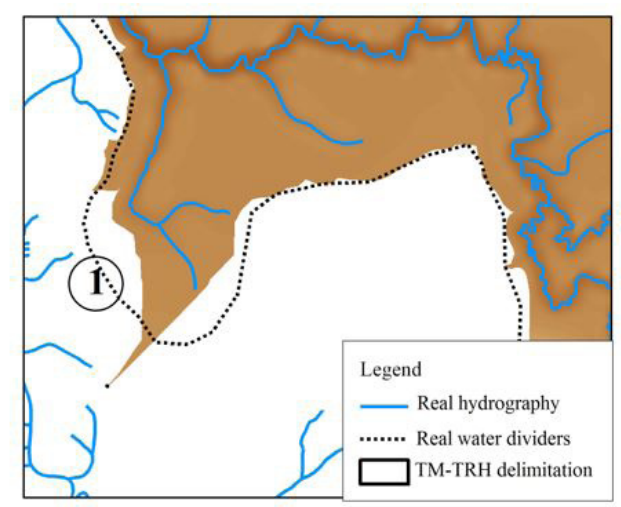

(b)

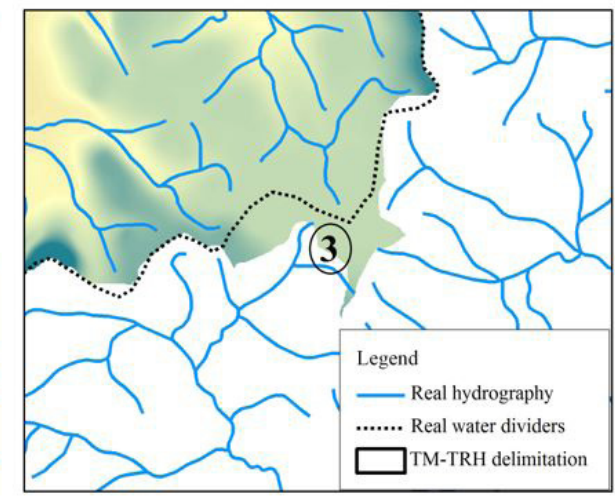

(d)

Figure 7. Main errors made in delimiting Peixe River Basin water dividers using the IBGE topographic maps with mapped hydrography support (TM-TRH DEM). 
dividers. However, some faults were observed such as the inclusion of a small drainage area of the neighboring basin (Figure 7d) in the São Francisco Plateau region and the exclusion of a small basin drainage area (Figures 7b and 7c) in the São Franciscana Depression.

\section{CONCLUSIONS}

i) The models generated with SRTM data and topographic maps with the mapped hydrography support presented good precision, with small basin delimitation errors. They are indicated for in situ studies;

ii)The models generated without the mapped hydrography support presented gross errors due to the non-representativeness of the hydrography in the São Franciscana Depression region. These errors serve as an alert for the academic community and water resource managers about the need to verify the accuracy of the DEM before use;

iii) The results were obtained and are valid for the scale of $1,100,000$. Therefore, it is advisable to perform other studies in other relief transition regions similar or not to this study, with different scales or not, and with different SRTM resolution (cell size of $30 \times 30 \mathrm{~m}$ ) for a more solid conclusion on the accuracy of these models. It is noteworthy that the $30 \mathrm{~m}$ SRTM DEM is available for download on the USGS website (NASA, 2018).

\section{ACKNOWLEDGEMENTS}

The authors would like to thank FAPEMIG for granting a scholarship to the first author, which was fundamental for the accomplishment of the work.

\section{SUBMISSION STATUS}

Received: 11 june, 2016

Accepted: 10 june, 2018

\section{CORRESPONDENCE TO}

\section{Donizete Pereira}

Universidade Federal de Viçosa - UFV, Rodovia LMG 818, Km 6, CEP 35690-000, Florestal, MG, Brasil

e-mail: doniagri@yahoo.com.br

\section{REFERENCES}

Alcaraz SA, Sannier C, Vitorino ACT, Daniel O. Comparison of methodologies for automatic generation of limits and drainage networks for hidrographic basins. Revista Brasileira de Engenharia Agrícola e Ambiental 2009; 13(4): 369-375. http://dx.doi.org/10.1590/S1415-43662009000400001.

Alves T So, Oliveira PTS, Rodrigues DBB, Ayres FM. Delimitação automática de bacias hidrográficas utilizando dados SRTM. Engenharia Agrícola 2010; 30(1): 46-57. http://dx.doi.org/10.1590/S0100-69162010000100005.

Bertoni J, Lombardi F No. Conservação do solo. 6. ed. São Paulo: Ícone; 2008.

Ceballos A, Schnabel S. Hydrological behavior of a small catchment in the dehesa landuse system (Extremadure, SW Spain). Journal of Hydrology 1998; 210(1-4): 146-160. http://dx.doi.org/10.1016/S0022-1694(98)00180-2.

Cecílio RA, Coutinho LM, Xavier AC, Moreira MC, Zanetti SS, Garcia GO. Delimitação de bacia hidrográfica em região montanhosa a partir de diferentes modelos digitais de elevação. Semina: Ciências Agrárias 2013; 34(5): 2007-2024. http://dx.doi.org/10.5433/1679-0359.2013v34n5p2007.

Choi JY, Engel BA. Real-time watershed delineation system using Web-GIS. Journal of Computing in Civil Engineering 2003; 17(3): 189-196. http://dx.doi.org/10.1061/ (ASCE)0887-3801(2003)17:3(189).

Environmental Systems Research Institute - ESRI. ArcGIS Professional GIS for the desktop. version 9.3 [software]. Redlands: ESRI; 2008.

Fairfield J, Leymarie P. Drainage networks from grid digital elevation models. Water Resources Research 1991; 27(5): 709-717. http://dx.doi.org/10.1029/90WR02658.

Ferrari JL, Silva SF, Santos AR, Garcia RF. Análise morfométrica da sub-bacia hidrográfica do córrego Horizonte, Alegre, ES. Agrária 2013; 8(2): 181-188. http:// dx.doi.org/10.5039/agraria.v8i2a1575.

Garbrecht J, Martz LW. Network and subwatershed parameters extracted from digital elevation models: the bills creek experience. Journal of the American Water Resources Association 1993; 29(6): 909-916. http://dx.doi. org/10.1111/j.1752-1688.1993.tb03251.x.

Instituto Brasileiro de Geografia e Estatística - IBGE. Mapa de solos do Brasil [online]. Rio de Janeiro: IBGE; 2002 [cited 2015 July 17]. Available from: ftp://geoftp. ibge.gov.br/mapas_tematicos/mapas_murais/solos.pdf

Instituto de Geociências Aplicadas - IGA. Atlas digital de Minas Gerais: geomorfologia [online]. Belo Horizonte: IGA; 2016 [cited 2016 May 20]. Available from: http:// www.iga.mg.gov.br/mapserv_iga/atlas/TutorialPDF/7Geomorfologia.pdf

Lindsay JB, Rothwell JJ, Davies H. Mapping outlet points used for watershed delineation onto DEM-derived stream networks. Water Resources Research 2008; 44(8): W08442. http://dx.doi.org/10.1029/2007WR006507. 
Medeiros LC, Ferreira NC, Ferreira LG. Avaliação de modelos digitais de elevação para delimitação automática de bacias hidrográficas. Revista Brasileira de Cartografia 2009; 61(2): 137-151.

National Aeronautics and Space Administration - NASA. Shuttle radar topography mission [online]. Washington; 2018 [cited 2018 July 6]. Available from: http://www2. jpl.nasa.gov/srtm/index.html

O'Callaghan JF, Mark DM. The extraction of drainage networks from digital elevation data. Computer Vision Graphics and Image Processing 1984; 28(3): 323-344. http:// dx.doi.org/10.1016/S0734-189X(84)80011-0.

Oliveira PTS, Alves T So, Steffen JL, Rodrigues DBB. Caracterização morfométrica de bacias hidrográficas através de dados SRTM. Revista Brasileira de Engenharia Agrícola e Ambiental 2010; 14(8): 819-825. http://dx.doi. org/10.1590/S1415-43662010000800005.

Pinheiro ES. Comparação entre dados altimétricos Shuttle Radar Topography Mission, cartas topográficas e GPS: Numa área com relevo escarpado. Revista Brasileira de Cartografia 2006; 58(1): 1-9.

Rabus B, Eineder M, Roth A, Bamler R. The shuttle radar topography mission - a new class of digital elevation models acquired by spaceborne radar. ISPRS Journal of Photogrammetry and Remote Sensing 2003; 57(4): 241262. http://dx.doi.org/10.1016/S0924-2716(02)00124-7.

Rawat KS, Krishna G, Mishra A, Singh J, Mishra SV. Effect of DEM data resolution on low relief region sub- watershed boundaries delineating using of SWAT model and DEM derived from CARTOSAT-1 (IRS-P5), SRTM and ASTER. Journal of Applied and Natural Science 2014; 6(1): 144-151. http://dx.doi.org/10.31018/jans.v6i1.391.

Ribeiro C, Pires J, Nascimento M, Santana R. Análise da exatidão de diferentes métodos de interpolação para geração de modelos digitais de elevação e obtenção de características morfométricas em bacias hidrográficas. Revista Brasileira de Recursos Hídricos 2005; 10(2): 39-47. http://dx.doi.org/10.21168/rbrh.v10n2.p39-47.

Romano AW, Soares ACP. Geologia da folha Pará de Minas SE.23-Z-C-IV. Belo Horizonte: CPRM; 2007.

Saadi A. A geomorfologia da Serra do Espinhaço em Minas Gerais e de suas margens. Geonomos 1995; 3(1): 41-63.

Seyler F, Muller F, Cochonneau G, Guimarães L, Guyot JL. Watershed delineation for the Amazon sub-basin system using GTOPO30 DEM and a drainage network extracted from JERS SAR images. Hydrological Processes 2009; 23(22): 3173-3185. http://dx.doi.org/10.1002/hyp.7397.

Sodré RVR, Carvalho AO Jr, Machado WP, Oliveira SN, Gomes RAT, Guimarães RF. Classificação de bacias de drenagem do Alto Jequitaí (Minas Gerais) a partir da análise de principais componentes e análise de grupos. Revista Brasileira de Geomorfologia 2007; 8(2): 73-86. http://dx.doi.org/10.20502/rbg.v8i2.95.

Valeriano MM, Abdon MM. Aplicação de dados SRTM a estudos do Pantanal. Revista Brasileira de Cartografia 2007; 59(1): 63-71. 